\title{
Bringing sustainable seafood back to the table: exploring chefs' knowledge, attitudes and practices in Peru
}

\author{
Rocio López De La Lama, Santago De La Puente \\ and ARMANDO VALDÉS-VELÁSQUEZ
}

\begin{abstract}
Conservation organizations promoting sustainable seafood have had greater success when chefs are empowered as agents of change in favour of sustainable seafood. Peru is experiencing a gastronomic revolution with seafood at its core, and Peruvian top chefs are being approached by conservation organizations to become environmental advocates. Within this context we characterize the factors that influence chefs' behaviours regarding sustainable seafood. A total of 52 Peruvian top chefs were surveyed using the Knowledge, Attitudes and Practices Framework, complemented by a focus group with a subset of the surveyed population. Our results suggest that, regardless of their age or academic background, chefs are aware of the negative consequences that human activities have on the ocean and believe that restaurants have an obligation to become part of the solution by promoting the use of sustainable seafood. Nonetheless, three factors limit chefs' understanding of key concepts and prevent them from fully internalizing the environmental consequences of their actions in restaurants: (1) sustainability is a new topic for them, particularly for older chefs; (2) the fish species commonly used at restaurants are poorly regulated, and (3) chefs are risk averse to actions that could result in profit loss. Additionally, the structure of the seafood supply chain further limits chefs' capacity to act sustainably, even if they are aware of the need to change their behaviour. Recommendations are provided for future conservation campaigns advocating use of sustainable seafood, some of which have now been implemented.
\end{abstract}

Keywords Chef, conservation campaign, Knowledge, Attitudes and Practices Framework, Peru, restaurant, sustainable behaviour, sustainable seafood

Rocio López De La LAMA* (Corresponding author) Institute for Resources, Environment and Sustainability, The University of British Columbia, Vancouver, Canada. E-mail rocio.lopezdelalama@gmail.com

Santiago De La Puente Institute for the Oceans and Fisheries, The University of British Columbia, Vancouver, Canada

Armando VAldés-VelásqueZ Laboratorio de Estudios en Biodiversidad, and Facultad de Ciencias y Filosofía, Universidad Peruana Cayetano Heredia, Lima, Peru

*Also at: Laboratorio de Estudios en Biodiversidad, Universidad Peruana Cayetano Heredia, Lima, Peru

Received 17 April 2017. Revision requested 19 September 2017.

Accepted 5 February 2018. First published online 4 October 2018.
Supplementary material for this article is available at https://doi.org/10.1017/So030605318000273

\section{Introduction}

Tncrease in the popularity and profitability of seafood glo1 bally is resulting in the degradation of marine ecosystems (Jacquet et al., 2010). Thus the promotion of sustainable seafood has become a target for multiple conservation organizations. Sustainable seafood is broadly defined as wildcaught or farmed seafood whose production does not limit the long-term viability of the harvested species, marine ecosystem resilience, and the livelihoods of fisheriesdependent communities (Roheim, 2009; Jacquet et al., 2010).

Consumer empowerment initiatives (i.e. sustainable seafood guides) have failed to produce a major change in global seafood consumption patterns (Iles, 2004; Roheim, 2009; Jacquet et al., 2010; Parkes et al., 2010). Hence, conservation organizations are currently conducting interventions along the seafood value chain, seeking to guarantee a sustainable seafood supply rather than just focusing on the end consumer. These interventions have had greater apparent success, particularly when empowering chefs as agents of change in favour of sustainability (Ashoka, 2009). The underlying working assumption is that top chefs (i.e. successful, charismatic culinary trendsetters) have the power to influence consumer behaviour and encourage sustainable seafood consumption (Parkes et al., 2010).

Peru is a relevant case study for this topic. The country has been experiencing a gastronomic boom since 2006 (Matta, 2014). This has brought economic growth, development of farming and fishing communities, revaluation of traditional ingredients, and national integration (Wintersteen, 2012; Matta, 2014). Seafood is at the core of this process, with ceviche (a traditional entrée of marinated tiny pieces of raw fish) recognized as the Peruvian national dish (APEGA, 2013).

Top chefs working in Lima, Peru's capital and the epicentre of this culinary revolution, have been able to set new culinary trends, are at the centre of the cultural agenda, and have high media profiles (Matta, 2010; Wintersteen, 2012). They are a source of national pride and an inspiration for thousands of young chefs (Matta, 2010, 2014). 
TABLE 1 Sections and question types in the survey (Supplementary Material 1) used to interview chefs.

\begin{tabular}{|c|c|c|}
\hline Sections & Question types & Gathered information \\
\hline Background & 11 questions (closed \& multiple choice) & $\begin{array}{l}\text { Name, place of birth, education level, position at the restaurant } \\
\text { (chef or chef/owner), years working in the gastronomic in- } \\
\text { dustry, \& years working at current restaurant }\end{array}$ \\
\hline Restaurant profile & 4 questions (closed) & $\begin{array}{l}\text { Number of employees, clients per day, mean cost of a meal, } \\
\text { years of operation }\end{array}$ \\
\hline $\begin{array}{l}\text { Seafood purchasing } \\
\text { pathways \& patterns }\end{array}$ & 9 questions (closed \& multiple choice) & $\begin{array}{l}\text { Buying patterns (frequency, sourcing), top preferred seafood } \\
\text { (by species) \& identification of person in charge of purchase }\end{array}$ \\
\hline Knowledge & 9 questions (yes/no, single \& multiple choice) & $\begin{array}{l}\text { Knowledge about minimum landing sizes, fishing seasons, } \\
\text { catch of the day, sustainable seafood, \& governmental entity in } \\
\text { charge of regulating fisheries management \& seafood } \\
\text { consumption }\end{array}$ \\
\hline Attitudes & $\begin{array}{l}12 \text { questions (rankings: strongly agree, agree, } \\
\text { disagree, strongly disagree) }\end{array}$ & $\begin{array}{l}\text { Attitudes towards the marine fisheries crisis, sustainable sea- } \\
\text { food practices, implementation of sustainable seafood prac- } \\
\text { tices; self-perception of current sustainable seafood knowledge } \\
\text { \& practice, economic impact of implementing sustainable } \\
\text { seafood practices, \& restaurants as learning sites for chefs }\end{array}$ \\
\hline Practices & 4 questions (yes/no) & $\begin{array}{l}\text { Implementation of catch of the day, minimum landing sizes \& } \\
\text { fishing seasons at the restaurant }\end{array}$ \\
\hline
\end{tabular}

In 2011 Peru's most well-known chef, Gaston Acurio, acknowledged that environmental sustainability and social inclusion were core elements of his culinary ethics (García, 2013). This motivated the collaboration between top chefs and conservation organizations working in Peru to raise awareness about seafood sustainability (Wintersteen, 2012). However, neither the knowledge, attitudes and practices of chefs nor the drivers behind their motivation to seek and exclusively use sustainable seafood have been assessed.

Within this context, we sought to characterize the internal and external factors that influence the behaviour of chefs regarding sustainable seafood in Lima, and assess whether conservation actions should continue to prioritize chefs as key stakeholders and partners in the promotion of sustainable seafood in Peru.

\section{Methods}

The target population was top chefs working at high-end seafood restaurants (i.e. mean cost per customer in 2012 $>$ USD 20.00) in the coastal districts of Lima. Seventyeight restaurants met these criteria (Guía Gastronómica del Perú, 2011). All of their chefs were approached and 52 agreed to take part in the study.

The survey was designed using the Knowledge, Attitudes and Practices Framework (WHO, 2008; Launiala, 2009; Table 1, Supplementary Material 1). Surveys were conducted face to face at the restaurants by trained pollsters during 2013. Each survey took approximately $1 \mathrm{~h}$. Individual survey responses were anonymized before analysis.

The survey examined the knowledge, attitudes and practices of chefs regarding actions that could be implemented at the restaurant to foster the use of sustainable seafood: (1) respect for minimum landing sizes, using fishes that are larger than the smallest length at which it is legal to land and commercialize them; (2) respect for fishing seasons, using fishes that are caught only when it is legal to catch them; and (3) serving the catch of the day (i.e. using resources that are currently available, embracing local diversity and seasonality, and not focusing exclusively on highly demanded species; Ashoka, 2009).

Chefs' answers to the questions on the Knowledge (K), Attitudes (A) and Practices (P) sections of the survey (Table 1) were used to estimate K-, A- and P-scores. $\mathrm{K}$-scores were computed by adding the number of correct answers (e.g. the correct definition of minimum landing size), where each correct answer received one point. A-scores were computed by summing the number of responses aligned with pro-sustainable attitudes to seafood. Each favourable answer received one point, regardless of the magnitude of the response (e.g. 'agree' vs 'strongly agree' or 'disagree' vs 'strongly disagree'). P-scores were computed by summing the number of sustainable seafood practices that chefs claimed to implement at their restaurants at the time of the survey (the veracity of their claims was not tested). The Kruskal-Wallis test (with dunn.test 1.3.5 in $R$ 3.3.2; R Development Core Team, 2018) was used to compare KAP scores of chefs with incomplete and complete culinary training, and chefs $\leq 40$ years and $>40$ years of age.

A focus group was conducted with a subgroup of chefs to examine the survey results in-depth. Of $>20$ chefs invited to take part in the focus group only three attended, because of limited availability. The principal themes explored were the seafood supply chain, the preferences of 


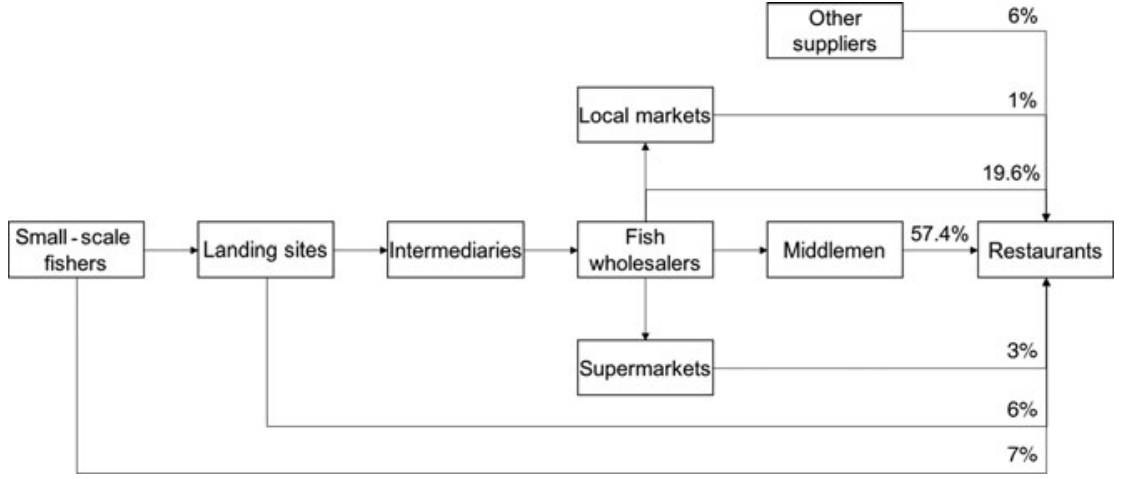

Fig. 1 Seafood supply chain for top restaurants in Lima, Peru, determined from interviews with 52 chefs. Per cent indicates the frequency of use of each pathway for seafood sourcing. consumers, and the power structure within the restaurant. The $1 \mathrm{~h} 20$ minute focus group was recorded, with the consent of the chefs, and later transcribed and coded to identify and analyse internal and external factors relevant to the chefs' capacity to purchase sustainable seafood.

\section{Results}

Chefs' profiles The chefs were predominantly male (92.3\%), with a mean age of $36.4 \pm \mathrm{SD} 10.2$ years (range 21-61 years). Most (75\%) were born in Lima, 17.3\% were from other Peruvian provinces and $7.7 \%$ were foreigners. Most chefs $(69.2 \%)$ had received culinary training either at a university or institute, and $75 \%$ of these had successfully completed their degree. Additionally, 17.3\% had completed higher education programmes in other fields (e.g. law, administration). The remaining chefs had not finished post-secondary studies $(3.9 \%)$ or had not pursued further studies after high school (9.6\%). On average, chefs had been working in the gastronomic industry for $14.3 \pm$ SD 8.6 years (range 1-39 years) and at their current restaurant for $7.2 \pm \mathrm{SD}_{7.4}$ years (range $0-32$ years). The restaurants charged USD $34.2 \pm$ SD 14.4 per consumer (range USD 22-74) for a complete meal, served $147 \pm$ SD 110 clients per day, and had $42 \pm \mathrm{SD} 28$ employees. Four participating chefs were also owners, or general managers, of their establishments.

Seafood supply chain The majority of chefs (77\%) stated that their restaurants acquire fish from wholesale seafood markets in Lima, via two possible mechanisms. The most common $(57.4 \%)$ is that the restaurant hires a middleman (i.e. a person or supply company) who goes to the wholesale market every morning, buys the best fresh fish available and delivers it to the restaurant. Alternatively, and less frequently (19.6\%), an employee of the restaurant, in some cases the chef, goes to the wholesale market to purchase the fish. Other seafood sourcing pathways included buying seafood directly from fishers (7\%), going to the landing sites to buy fresh seafood (6\%), buying seafood from supermarkets $(3 \%)$ or purchasing it from local markets in Lima (1\%). Some chefs stated that they also have access to seafood via other suppliers (6\%), mainly related to aquaculture and seafood importation (Fig. 1). Most restaurants bought seafood daily (56\%), or 3-4 times per week $(27 \%)$. Only $12 \%$ of chefs stated that their restaurants purchase seafood 2-3 times per week, and $5 \%$ purchased seafood less than once per week.

Seafood choices Chefs identified 35 fish species commonly used in restaurants: 31 wild-caught marine species and four farmed freshwater species. Seven species were identified as being the most popular: six wild-caught and one farmed (Table 2). Most of the popular species used at the restaurants were medium-large demersal fish, with high trophic levels (range 3.30-4.40; Froese \& Pauly, 2017) and characterized by their white meat (Zapata \& Noriega, 2008). The preferred species had moderate to very high vulnerabilities to extinction (Cheung et al., 2005), low to medium resilience, and reached maturity at 1.4-6 years (Froese \& Pauly, 2017). Only three of the top seven species had a regulated minimum landing size and none had regulated fishing seasons (Monteferri et al., 2017). The main drivers of use of these fishes varied by species but the most common reasons provided were 'commonly demanded by Peruvians' (27.2\%), 'good taste' (24.6\%), 'freshness' (11.0\%), 'good for multiple recipes' (9.2\%), 'white meat' (5.5\%), 'good price' (5.2\%) and 'large size' (2.9\%).

Knowledge All chefs had heard about fishing seasons, and $86.5 \%$ could define the concept correctly. However, minimum landing size, the catch of the day, and sustainable seafood were more elusive concepts for them: 40 chefs knew about minimum landing size (67.5\% adequately defined this), 44 chefs knew about catch of the day (52.3\% adequately defined this), and 41 chefs knew about sustainable seafood ( $92.7 \%$ adequately defined this). The Ministry of Production regulates fisheries 
TABLE 2 The seven most popular fish species at top seafood restaurants in Lima, Peru. The fishing season is unregulated for all these species.

\begin{tabular}{|c|c|c|c|c|c|c|c|c|}
\hline Species & $\begin{array}{l}\text { Trophic } \\
\text { level }^{1}\end{array}$ & Vulnerability $^{2}$ & Resilience $^{3}$ & $\begin{array}{l}\text { Age at first ma- } \\
\text { turity }^{4} \text { (years) }\end{array}$ & $\begin{array}{l}\text { Max. } \\
\text { length }^{5} \\
(\mathrm{~cm})\end{array}$ & $\begin{array}{l}\text { Min. landing } \\
\operatorname{size}^{6}(\mathrm{~cm})\end{array}$ & $\begin{array}{l}\% \text { of chefs } \\
\text { using }(n)\end{array}$ & Main criteria for usage ${ }^{7}$ ( $\%$ of chefs) \\
\hline $\begin{array}{l}\text { Albacore Thunnus } \\
\text { alalunga }\end{array}$ & 4.3 & High & Medium & 2.7 & 140 & 60 & $63.50(33)$ & $\begin{array}{l}\text { Consumer preference (31.3\%), good taste } \\
(29.7 \%)\end{array}$ \\
\hline $\begin{array}{l}\text { Fine flounder Paralichthys } \\
\text { adspersus }\end{array}$ & 4.2 & $\begin{array}{l}\text { Moderate to } \\
\text { high }\end{array}$ & Low & 3.8 & 70 & 50 & $48.10(25)$ & $\begin{array}{l}\text { Consumer preference (34.9\%), good taste } \\
(18.6 \%)\end{array}$ \\
\hline $\begin{array}{l}\text { Atlantic salmon Salmo } \\
\text { salar }\end{array}$ & 4.4 & High & Medium & 1.4 & 150 & Unregulated & $40.40(21)$ & $\begin{array}{l}\text { Consumer preference (31.6\%), good taste } \\
(29.0 \%)\end{array}$ \\
\hline $\begin{array}{l}\text { Corvina drum Cilus } \\
\text { gilberti }\end{array}$ & 3.7 & Moderate & Medium & 2.2 & 60 & 55 & $40.40(21)$ & $\begin{array}{l}\text { Freshness }(20.00 \%) \text {, good taste }(17.1 \%) \text {, } \\
\text { good for multiple recipes }(17.1 \%)\end{array}$ \\
\hline $\begin{array}{l}\text { Cachema weakfish } \\
\text { Cynoscion phoxocephalus }\end{array}$ & 3.8 & Moderate & Medium & 2.2 & 60 & Unregulated & $34.60(18)$ & $\begin{array}{l}\text { Consumer preference (32.1\%), good taste } \\
(25.0 \%)\end{array}$ \\
\hline $\begin{array}{l}\text { Peruvian grunt } \\
\text { Anisotremus scapularis }\end{array}$ & 3.7 & Moderate & Medium & 2.6 & 40 & Unregulated & $26.90(14)$ & $\begin{array}{l}\text { Good taste }(22.5 \%) \text {, consumer preference } \\
(17.5 \%) \text {, good for multiple recipes } \\
(15.0 \%)\end{array}$ \\
\hline $\begin{array}{l}\text { Spotted grouper } \\
\text { Epinephelus analogus }\end{array}$ & 3.8 & $\begin{array}{l}\text { High to very } \\
\text { high }\end{array}$ & Medium & 6.0 & 114 & Unregulated & $26.90(14)$ & $\begin{array}{l}\text { Consumer preference }(29.2 \%) \text {, good taste } \\
(29.2 \%) \text {, freshness }(12.5 \%)\end{array}$ \\
\hline
\end{tabular}

${ }^{1}$ Position in the food chain, determined by the number of energy-transfer steps to that level (Froese \& Pauly, 2017).

${ }^{2} \mathrm{An}$ index of intrinsic vulnerability to extinction that includes life history and ecological characteristics of the target species (Cheung et al., 2005).

${ }^{3}$ The capacity to withstand exploitation (Froese \& Pauly, 2017).

${ }^{4}$ Age at which $50 \%$ of a cohort spawn for the first time (Froese \& Pauly, 2017).

${ }^{5}$ Maximum recorded length (Froese \& Pauly, 2017).

${ }^{6}$ See Methods.

${ }^{7}$ Reasons stated for using a particular species. 
TABLE 3 Chefs' knowledge, attitude and practice scores, and statistical comparison among subsets of the surveyed population.

\begin{tabular}{|c|c|c|c|}
\hline Groups & $\mathrm{n}$ & Mean \pm SD & Kruskal-Wallis test $\mathrm{P}$ \\
\hline \multicolumn{4}{|l|}{ Knowledge score } \\
\hline All surveyed chefs & 52 & $6.4 \pm 2.0$ & \\
\hline Chefs with complete culinary training & 27 & $7.1 \pm 1.8$ & \\
\hline Chefs without (or with incomplete) culinary training & 25 & $5.7 \pm 2.1$ & \\
\hline Chefs with complete culinary training vs all others & & & $0.02^{*}$ \\
\hline Younger chefs (age $\leq 40$ years) & 38 & $6.8 \pm 2.0$ & \\
\hline Older chefs (age $>40$ years) & 14 & $5.5 \pm 1.9$ & \\
\hline Younger vs older chefs & & & $0.02^{*}$ \\
\hline \multicolumn{4}{|l|}{ Attitude score } \\
\hline All surveyed chefs & 52 & $10.1 \pm 0.5$ & \\
\hline Chefs with complete culinary training & 27 & $10.5 \pm 1.0$ & \\
\hline Chefs without (or with incomplete) culinary training & 25 & $9.6 \pm 1.7$ & \\
\hline Chefs with complete culinary training vs all others & & & 0.08 \\
\hline Younger chefs (age $\leq 40$ years) & 38 & $10.3 \pm 1.3$ & \\
\hline Older chefs (age $>40$ years) & 14 & $9.6 \pm 1.9$ & \\
\hline Younger vs older chefs & & & 0.28 \\
\hline \multicolumn{4}{|l|}{ Practice score } \\
\hline All surveyed chefs & 52 & $3.3 \pm 0.9$ & \\
\hline Chefs with complete culinary training & 27 & $3.5 \pm 0.8$ & \\
\hline Chefs without (or with incomplete) culinary training & 25 & $3.0 \pm 0.9$ & \\
\hline Chefs with complete culinary training vs all others & & & $0.03^{*}$ \\
\hline Younger chefs (age $\leq 40$ years) & 38 & $3.3 \pm 0.9$ & \\
\hline Older chefs (age $>40$ years) & 14 & $3.1 \pm 0.8$ & \\
\hline Younger vs older chefs & & & 0.25 \\
\hline
\end{tabular}

${ }^{\star} \mathrm{P}<0.05$.

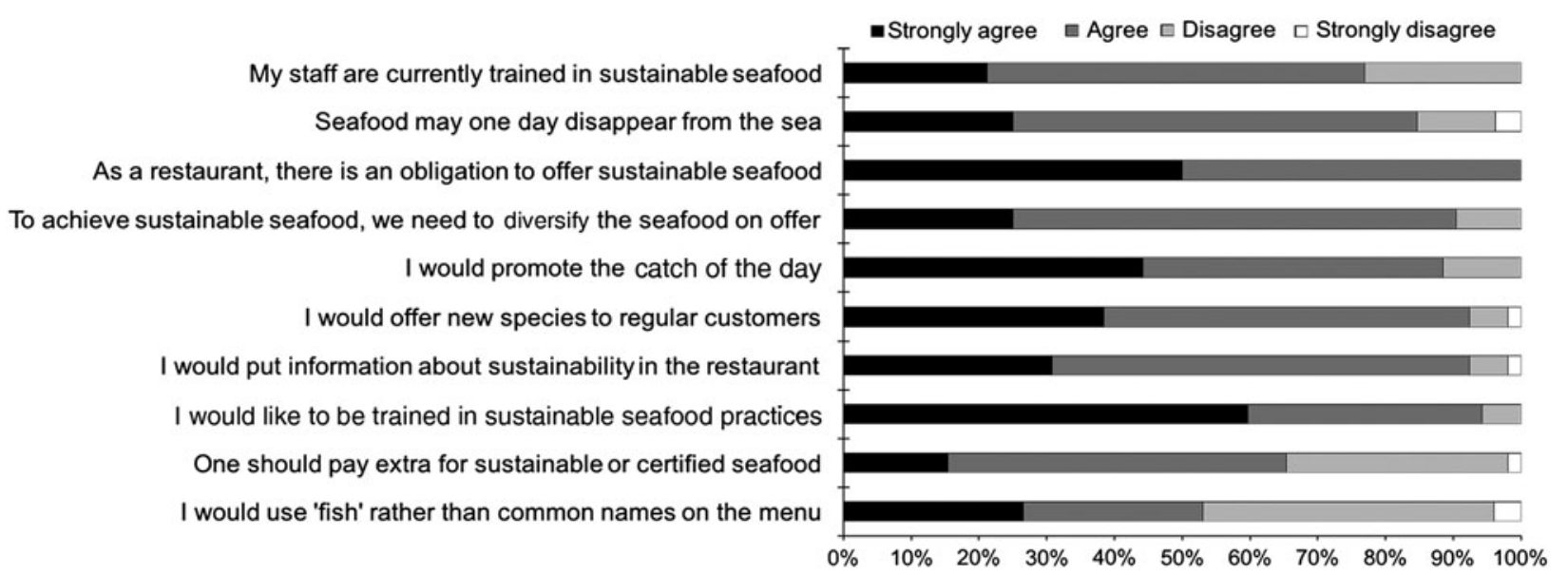

FIG. 2 Attitude profiles of the surveyed chefs.

management and seafood trade in Peru (PRODUCE, 2017) but less than half of the participants $(46.2 \%)$ identified the Ministry as the regulating authority in these matters. Common misconceptions included The Ministry of the Environment (23.1\%), district-level municipalities (13.7\%), the ecological police (5.8\%), and the Peruvian Navy (1.9\%). The mean K-score of chefs was 6.4 \pm SD 2.0 (range 2-9). Younger chefs (age $\leq 40$ ) and chefs who had completed their culinary studies had significantly higher K-scores than their counterparts $(\mathrm{P}<0.02$, Table 3$)$.
Attitudes Chefs had positive attitudes towards sustainable seafood (Fig. 2), with mean A-scores of $10.1 \pm \mathrm{SD} 1.5$ (range 6-12). Their age and/or training had no effect on their respective A-scores $(\mathrm{P}>0.05$, Table 3$)$. Some inconsistencies were detected in their responses. For example, all chefs believed that 'restaurants have the obligation to offer sustainably sourced seafood', $84.6 \%$ believed that 'fish may one day disappear from the sea', $82.7 \%$ believed that complying with seafood regulations (e.g. minimum landing size) does not impact their profit margin, but $65.4 \%$ believed 
that 'restaurants should pay extra for sustainable or certified seafood'. Similarly, $90.4 \%$ of the chefs believed they need to diversify their seafood choices to achieve sustainable seafood, 92.3\% 'would offer new species to their regular customers', and $88.4 \%$ were willing to use the catch of the day. However, only $53.1 \%$ of participating chefs would abandon the use of common names, e.g. fine flounder (Paralichthys adspersus), on their menus in favour of generic denominations such as 'fish' or 'catch of the day'. Finally, $76.9 \%$ of the chefs believed that they and their staff had sufficient training to face the challenges of using sustainable seafood, but $94.2 \%$ 'would like to receive further training' on the topic. Furthermore, $92.3 \%$ 'would include information about seafood sustainability in their restaurant', and $90.4 \%$ see restaurants as 'information exchange sites' for other chefs (e.g. places to learn about seafood, cooking techniques).

Practices All chefs claimed to respect fishing seasons and $84.6 \%$ claimed to comply with minimum landing size regulations. Moreover, $65.4 \%$ of the chefs claimed their restaurants offered the catch of the day at the time of the survey, and $75 \%$ claimed that customers received information about seafood diversity at their restaurants. The mean P-scores of chefs were $3.3 \pm$ SD 0.9 (range 1-4). Chefs with complete culinary training had significantly higher $\mathrm{P}$-scores $(\mathrm{P}=0.03$, Table 3$)$.

\section{Barriers to the exclusive use of sustainably sourced seafood} In the focus group, the chefs reflected on what they considered to be the main barriers to the use of sustainable seafood in their restaurants. Chefs claimed they would like to purchase high-quality fish directly from small-scale fishers that catch seafood in a sustainable manner. They argued that in this way they could also increase their profit margins by 'cutting out the middlemen'. Although chefs had 'tried their best' to do so, they had not been successful because fishers 'are not properly organized' and thus they 'can't be trusted as a reliable source of high-quality fish'. Chefs claimed that when attempting to work directly with fishers the 'fish was not properly refrigerated', that fishers 'failed to comply with the amount of seafood demanded by the restaurant and/or the frequency at which they needed to receive it', and that fishers 'don't provide receipts' and 'default on down-payments'. Chefs argued that these issues have 'strengthened the role that the middlemen play in the seafood value chain', and they felt the need to 'maintain their suppliers', as few of them can cater to high-quality standards and competition is increasing with the expansion of the restaurant business in Peru. Thus, they must sometimes 'purchase non-desired fish or fish that is evidently below the minimum landing size' as part of 'package deals offered by the middlemen'. Additionally, although they are the main target of multiple sustainable seafood campaigns, many 'lack the power to make critical decisions inside the restaurant'. This is because chefs are rarely owners or managers of the restaurants where they work, and 'the administrative body won't allow for innovations that might risk profit margins'. Furthermore, even if the owners and chefs are in favour of only serving sustainable seafood, 'the time and energy required to look for sustainable suppliers' and 'build a relationship of trust' with them is too great. In other words, the transitional costs towards sustainable seafood are perceived to 'be too high and not recognized sufficiently by the consumers'. Finally, chefs claimed that Peruvian consumers have strong preferences for certain fish species and that these preferences are not based on the quality and taste of the fish, but on the economic status that purchasing luxury species grants them'. Chefs stated that if they were to 'stop offering traditional species favoured by consumers' they would 'just move to another restaurant' as 'Lima offers a wide range of seafood restaurants', and this perception leads to seafood mislabelling. For example, a chef stated, 'when we offer corvina drum [Cilus gilberti] we are most likely serving cachema weakfish [Cynoscion phoxocephalus] instead, because their taste, size and texture are indistinguishable on the plate and the consumers prefer to believe they are eating that fish'.

\section{Discussion}

The chefs interviewed for this study are trendsetters and leaders of the Peruvian gastronomic revolution (Wintersteen, 2012; Matta, 2014). Our results suggest they are aware of the negative consequences that human activities have on the ocean and believe that restaurants have the obligation to become part of the solution by promoting the use of sustainable seafood, regardless of their age or academic background. Nonetheless, three factors limit their understanding of key concepts and prevent them from fully internalizing the environmental consequences of their actions in the restaurants.

Firstly, sustainability is a new topic, particularly for older chefs. Chefs have not necessarily been exposed to the linkages between gastronomy and environmental sustainability, as this is not a topic generally addressed in the curricula of local culinary schools (APEGA, 2010), and completing formal culinary training is not a mandatory requirement to work at the most exclusive restaurants in the country. However, as younger generations and informed citizens are generally more concerned about environmental issues (Olofsson \& Öhman, 2006; Bucic et al., 2012; Twenge et al., 2012), it is unsurprising that younger chefs and those who had completed culinary studies had higher $\mathrm{K}$-scores than their counterparts.

Secondly, the fish species commonly used at restaurants are poorly regulated. Fishes offered by restaurants generally 
lack catch and effort limits, fishing seasons and minimum landing sizes (Monteferri et al., 2017). Chefs learn about these through consumer awareness campaigns (such as bóVEDA, led by the NGO ProDelphinus, and El Tamaño Sí Importa led by WWF-Peru; Monteferri et al., 2017), or through the news media, as they are hardly ever inspected by government officials to enforce such regulations. This may explain why the chefs that could not properly identify which government institution is in charge of regulating/managing the fisheries claimed to be implementing sustainable seafood policies at their restaurants (e.g. respecting fishing seasons and minimum landing sizes) with no additional costs, and why chefs are more aware of fishing seasons than minimum landing sizes although the latter are more relevant for them (none of the fish species offered by the restaurants during the survey had a regulated fishing season; Monteferri et al., 2017).

Thirdly, chefs are risk averse to actions that could result in profit loss. Chefs claim that consumer preference is the main driver for seafood selection, and that consumers 'don't value sustainability'. Several species served at their restaurants are regarded as luxury goods in Peru, accessible only to the wealthy, including fine flounder, corvina drum, Peruvian grunt Anisotremus scapularis and grouper Epinephelus analogus (Zapata \& Noriega, 2008). As seen in the Chinese market, an emerging middle class feels the need to demand gourmet items to demonstrate their improved status (Eriksson \& Clarke, 2015). Conversely, consumers' willingness to pay for environmental attributes in seafood depends on their education, socio-economic background and the explicit benefits of the product, among others (Hilger et al., 2015). These could explain why the sustainable seafood practices least favoured by chefs were paying premiums for sustainable or certified seafood, and implementing the catch of the day (Parkes et al., 2010). Chefs also use these arguments to justify their seafood mislabelling practices, which reduce consumers' awareness of the need to change their consumption patterns, and lead to further depletion of vulnerable resources (Jacquet et al., 2010; Warner et al., 2013; Hilger et al., 2015).

Additionally, the structure of the seafood supply chain further limits the capacity of chefs to act sustainably, even if they are aware of the need to change their behaviour. As revealed during the focus group, chefs fear that rejecting fishes because of concerns over sustainability (i.e. too small or out of season) will weaken their commercial relationship with middlemen.

Middlemen are the primary seafood suppliers of restaurants, releasing chefs from the complex logistics associated with the daily distribution of fresh fish. Middlemen outcompete fishers venturing into the seafood trade (i.e. they deliver high-quality seafood to the restaurants on time, and provide receipts) and restaurants that opt to purchase seafood from wholesalers (i.e. middlemen have connections with trusted vendors, supply high-quality seafood in a consistent manner, and operate in areas and at times that work for both the restaurant and the wholesalers).

Middlemen have privileged access to information regarding seafood diversity, availability and prices at the wholesalers, and thus the power balance is tilted in their favour. Moreover, middlemen are not regulated by law and the government lacks data to understand and monitor their role in the supply chain (Sueiro \& De la Puente, 2015). These issues are potentially a problem for Peruvian gastronomy because fishes are regularly caught and traded below their minimum landing sizes (Doherty et al., 2014; Sueiro \& De la Puente, 2015), and the landings of species in high demand (i.e. large coastal demersal species of high trophic levels) have declined since 1999 (Caillaux, 2011).

Based on our findings and their implications, we make the following recommendations for future conservation campaigns advocating sustainable seafood:

1) Develop and strengthen the capacities of top chefs to advocate for, and demand, sustainably sourced seafood. They should receive training on the key concepts and practices they are advocating, focusing in particular on older chefs who did not attend culinary school.

2) Organizations working in favour of sustainable seafood should promote the incorporation of sustainable gastronomy as a core learning objective on the curricula of culinary schools. By working with these institutions, sustainable seafood advocates can enrol future allies early on in their careers, before unsustainable practices become established as behavioural norms.

3) Seafood campaigns should target restaurants rather than chefs. Restaurants are important knowledgeexchange sites that employ large numbers of staff in Lima and serve up to 500 customers per day. This makes them valuable case studies for assessing and communicating the benefits and importance of sustainable seafood consumption. Moreover, this change would facilitate the targeting of those who make the business decisions at the restaurants (i.e. managers and owners) and perhaps influence their seafood purchasing practices.

4) Middlemen are key stakeholders that require more attention and perhaps governmental control. By working with this group, restaurants' transitional cost for implementing sustainable seafood practices could be reduced, whilst potentially diminishing markets for unsustainably caught seafood, and improving seafood traceability (Jacquet et al., 2010).

5) Conservation organizations should monitor sustainable seafood practices in restaurants and rank them accordingly. Although top chefs have high media profiles and could be allies in sustainable seafood campaigns, their restaurants may face internal and/or external pressures that could lead to unsustainable seafood 
practices. If consumers are unaware of this, conservation organizations are only increasing the chefs' profiles without making them accountable for their restaurants' behaviour concerning seafood. If restaurants and chefs are shamed for unsustainable practices and honoured for sustainable ones, this could lead to an easier transition to consumption of sustainable seafood (Jacquet et al., 2011).

We presented our main results and recommendations to chefs and interested institutions in a public talk in 2013, and distributed a booklet to all participating restaurants and interested stakeholders (e.g. NGOs, universities). Several initiatives have since been implemented that foster sustainable seafood consumption. In 2014 key stakeholders (Ministry of Production, Food and Agriculture Organization of the UN, WWF-Peru, fisheries associations, universities and the Peruvian Gastronomic Society) signed an agreement, with 10 principles, to work in favour of responsible fisheries (MINAM, 2014). In 2016 the Ministry of Production started a programme (From the port to the table) that aims to link fishers with high-end restaurants, cutting out middlemen and paying a premium for responsibly sourced and highquality seafood (Programa Nacional 'A Comer Pescado', 2017), and the group Generación con Causa was created, comprising the chefs who are participating in the Peruvian gastronomic revolution and that are fully committed to implementing sustainable and inclusive gastronomic practices throughout the country (Generación con Causa, 2017).

Acknowledgements We thank the chefs and their restaurants who agreed to participate, the Rufford Foundation (Project No.12293-1) for funding, Patricia Majluf and Juan Carlos Sueiro from Oceana-Peru for insightful ideas and advice, and the many volunteers for their assistance with data collection.

Author contributions Survey design, data collection and analysis, writing: RL; data analysis, writing: SDLP; supervision of survey design, advice, revision of text: AV.

\section{Conflicts of interest None.}

Ethical standards This research was approved by the Ethics Committee of Cayetano Heredia University, Lima, Peru (Project No. 59727). Participants gave their informed written consent.

\section{References}

APEGA (2010) Carreras de cocina. Informe de la oferta académica en Lima y regiones. Sociedad Peruana de Gastronomía, Lima, Perú. APEGA (2013) El boom gastronómico peruano al 2013. Sociedad Peruana de Gastronomía, Lima, Perú.

AsHoкA (2009) Changing the Future of Wild Fish. An Entrepreneurial Approach to Sustainable Solutions. Report commissioned by: The David and Lucile Packard Foundation. 19op. Http://futureoffish.org/ sites/default/files/docs/resources/Phase\%201\%20Future\%20of\% 2oWild\%2oFish\%2oReport.pdf [accessed 20 December 2017].
BuCIC, T., Harris, J. \& ArLI, D. (2012) Ethical consumers among the millennials: a cross-national study. Journal of Business Ethics, 110, $113-131$.

Caillaux, M. (2011) Cambios en el Índice Trófico Marino de las capturas de los principales recursos pesqueros de la costa peruana desde el año 1950 hasta el 2008. BSc thesis. Universidad Nacional Agraria La Molina, Lima, Peru.

Cheung, W.W.L., Pitcher, T.J. \& Pauly, D. (2005) A fuzzy logic expert system to estimate intrinsic extinction vulnerabilities of marine fishes to fishing. Biological Conservation, 124, 97-111.

Doherty, P.D., Alfaro-Shigueto, J., Hodgson, D., Mangel, J., Witt, M. \& Godley, B. (2014) Big catch, little sharks: insight into Peruvian small-scale longline fisheries. Ecology and Evolution, 4, 2375-2383.

Eriksson, H. \& Clarke, S. (2015) Chinese market responses to overexploitation of sharks and sea cucumbers. Biological Conservation, 184, 163-173.

Froese, R. \& Pauly, D. (2017) FishBase. Http://www.fishbase.org [accessed 22 September 2017].

García, M.E. (2013) The taste of conquest: colonialism, cosmopolitics, and the dark side of Peru's gastronomic boom. The Journal of Latin American and Caribbean Anthropology, 18, 505-524.

Generación con Causa (2017) ¿Qué es Generación con Causa? Https://peru.info/es-pe/generacionconcausa/que-es [accessed 16 December 2017].

Guía Gastronómica del Perú (2011) El Manual del Buen Gourmet 2011. IDEAS, Lima, Perú.

Hilger, J., Hallstein, E., Stevens, A. \& Villas-Boas, S. (2015) Measuring Willingness to Pay for Environmental Attributes in Seafood. Department of Agricultural and Resource Economics Working Papers. University of California Berkeley, Berkeley, USA.

ILEs, A. (2004) Making seafood sustainable: merging consumption and citizenship in the United States. Science and Public Policy, 31, 127-138.

Jacquet, J., Hocevar, J., Lai, S., Majluf, P., Pelletier, N., Pitcher, T. et al. (2010) Conserving wild fish in a sea of market-based efforts. Oryx, 44, 45-56.

Jacquet, J., Hauert, C., Traulsen, A. \& Milinski, M. (2011) Shame and honour drive cooperation. Biology Letters, 7, 899-901.

LaUniala, A. (2009) How much can a KAP survey tell us about people's knowledge, attitudes and practices? Some observations from medical anthropology research on malaria in pregnancy in Malawi. Anthropology Matters, 11, 1-13.

MatTA, R. (2010) Cocina y clases: la revolución gastronómica peruana y sus chefs mediáticos. Http://revistaargumentos.iep.org.pe/ articulos/cocina-y-clases-la-revolucion-gastronomica-peruana-ysus-chefs-mediaticos/ [accessed 16 December 2017].

MatTA, R. (2014) República gastronómica y país de cocineros: comida, política, medios y una nueva idea de nación para el Perú. Revista Colombiana de Antropología, 50, 15-40.

MINAM (2014) Se firman Diez Compromisos por la pesca responsable y sostenible en Voces por el Clima. Ministerio del Ambiente del Perú. Http://www.minam.gob.pe/notas-de-prensa/se-firman-diezcompromisos-por-la-pesca-responsable-y-sostenible-en-vocespor-el-clima/ [accessed 16 December 2017].

Monteferri, B., Bengolea, C., Scheske, C. \& Ruiz, M. (2017) Advancing Sustainable Fisheries Reforms in Peru - Looking at the Future (2017-Onwards). A report by the Peruvian Society for Environmental Law, prepared for the Environmental Defense Fund, Lima, Peru.

Olofsson, A. \& Öhman, S. (2006) General beliefs and environmental concern: transatlantic comparisons. Environment and Behavior, 38 , 768-790. 
Parkes, G., Young, J.A., Walmsley, S.F., Abel, R., Harman, J., Horvat, P. et al. (2010) Behind the signs-a global review of fish sustainability information schemes. Reviews in Fisheries Science, 18, 344-356.

PRODUCE (2017) Reglamento de Organización de Funciones del Ministerio de la Producción del Perú (Decreto Supremo No. o02-2017-PRODUCE). Lima, Peru.

Programa Nacional "A Comer Pescado" (2017) Pescadores $y$ acuicultores se reunirán con grandes compradores en Lima. Http://www.acomerpescado.gob.pe/pescadores-y-acuicultores-sereuniran-con-grandes-compradores-en-lima [accessed 16 December 2017].

R Development Core Team (2018) R: A Language and Environment for Statistical Computing. R Foundation for Statistical Computing, Vienna, Austria. Https://www.R-project.org/ [accessed 20 August 2018].

Roheim, C.A. (2009) An evaluation of sustainable seafood guides: implications for environmental groups and the seafood industry. Marine Resource Economics, 24, 301-310.

Sueiro, J.C. \& De la Puente, S. (2015) La pesca artesanal en el Perú: Diagnóstico de la actividad pesquera artesanal peruana. 2nd edition.
Centro para la Sostenibilidad Ambiental de la Universidad Peruana Cayetano Heredia, Lima, Perú.

Twenge, J.M., Campbell, W.K. \& Freeman, E.C. (2012) Generational differences in young adults' life goals, concern for others, and civic orientation, 1966-2009. Journal of Personality and Social Psychology, 102, 1045-1062.

Warner, K., Timme, W., Lowell, B. \& Hirshfield, M. (2013)

Oceana Study Reveals Seafood Fraud Nationwide. Http://oceana.org/ sites/default/files/reports/National_Seafood_Fraud_Testing Results_FINAL.pdf [accessed 15 December 2017].

Who (World Health Organization) (2008) Advocacy, Communication and Social Mobilization for TB Control. A Guide to Developing Knowledge, Attitude and Practice Surveys. World Health Organization, Geneva, Switzerland.

Wintersteen, K. (2012) Sustainable gastronomy. A market-based strategy for improving environmental sustainability in the Peruvian anchoveta fishery. In Environmental Leadership: A Reference Handbook, Vols. 1 \& 2 (ed. D.R. Gallagher), pp. 626-634. Sage Publications, Inc., Thousand Oaks, USA.

Zapata, S. \& Noriega, C. (2008) Recursos Hidrobiológicos en la Gastronomía Peruana. Universidad San Martín de Porres, Lima, Perú. 